\title{
Nitrogen dynamics of a cyanobacteria bloom in the Baltic Sea: new versus regenerated production
}

\author{
Fred Sörensson \& Elisabeth Sahlsten
}

Department of Marine Microbiology, University of Göteborg, Carl Skottsbergs Gata 22, S-413 19 Göteborg, Sweden

\begin{abstract}
A bloom of nitrogen-fixing filamentous cyanobacteria was studied at a drift station in the Baltic Sea in July-August 1982. Uptake of combined nitrogen nutrients (ammonium, nitrate and urea) was measured using ${ }^{15} \mathrm{~N}$ labelled substrates, and was around $450 \mathrm{nmol} \mathrm{l}^{-1} \mathrm{~d}^{-1}$. New production (based on uptake of nitrate and $\mathrm{N}_{2}$ ) was only $27 \%$ of total $\mathrm{N}$ uptake. The major nitrogen source was ammonium, which constituted about half of the total nitrogen uptake measured. The nitrogen fixers seemed to rely mainly on $\mathrm{N}_{2}$ for their nitrogen demand, while the major part of nitrogen assimilation was carried out by smaller non-nitrogen-fixing phytoplankton, mainly utilizing regenerated nitrogen. The dissolved organic matter had a molar $\mathrm{C} / \mathrm{N}$ ratio of over 20 , and seemed mainly to be refractive. The particulate material had a $\mathrm{C} / \mathrm{N}$ ratio of 8.5 , and a N/P ratio of 19 . From ATP measurements, the amount of 'living carbon' was estimated to be $23 \%$ of the particulate carbon. Doubling time of the living fraction of the particulate nitrogen was approximately $1 \mathrm{~d}$.
\end{abstract}

\section{INTRODUCTION}

The limiting nutrient for primary production in the pelagic marine environment is generally considered to be nitrogen. This seems to be true also for the brackish Baltic proper (Larsson 1984). This is indicated by e.g. the low molar ratio of inorganic nitrogen to phosphate (1.3 to 4) before the spring bloom (Fonselius 1978) and enrichment experiments with Baltic waters (Granéli \& Granéli 1987). A substantial nitrogen input -100000 to 130000 tons of $\mathrm{N} \mathrm{yr}^{-1}$ (Lindahl et al. 1978, Rinne et al. 1978, Brattberg 1980), i.e. one-tenth of the total nitrogen input to the Baitic Sea (Larsson et al. 1985) - comes from blooms of filamentous cyanobacteria, of which Nodularia spumigena Mertens is often the most important nitrogen fixer. The blooms occur regularly in July and August every year, favoured by warm and calm weather after a turbulent period bringing phosphate to the surface water (Niemi 1979).

Most marine phytoplankton communities rely heavily on reduced-nitrogen sources such as ammonium and urea regenerated from organic compounds within the photic layer. The concept of 'new' and 'regenerated' production, based on the use of different nitrogen sources, was introduced by Dugdale \& Goering (1967), and has been further discussed by Eppley \& Peterson (1979). In the open sea, the amount of 'new' nitrogen uptake can give an estimate of the loss to deeper waters through sedimentation. In the present case, the nitrogen for 'new' production would be nitrate and dinitrogen gas $\left(\mathrm{N}_{2}\right)$, and the 'regenerated' forms would be ammonium and urea. The presence of a large population of nitrogen fixers might lead to the assumption that dinitrogen gas is the dominating nitrogen source. There are, however, several reasons why one should also consider the uptake of combined nitrogen sources. Firstly, organisms that fix nitrogen gas will use other nitrogen sources, especially reduced nitrogen like ammonium, if present. Secondly, in this area, there is usually a large population of primary producers present which is not capable of nitrogen fixation. These are mainly small flagellates, which have a high activity per biomass (Larsson \& Hagström 1982).

In 1982 a heavy bloom, with Nodularia spumigena as the major nitrogen-fixing species, was followed in a drift study, during which the same water mass was sampled over a $1 \mathrm{wk}$ period. This paper deals with the uptake of the most important combined nitrogenous nutrients, i.e. ammonium, nitrate and urea. In addition, concentrations of carbon and nitrogen in the particulate and dissolved matter are presented.

\section{MATERIALS AND METHODS}

The study was carried out between 26 July and $1 \mathrm{Au}$ gust 1982, as part of a joint Soviet-Swedish investigation concerning the physical and biological dynamics 
during a cyanobacteria bloom, on board the Soviet research vessel Georgii Ushakov. Stations were chosen by following a drogue at $15 \mathrm{~m}$ depth near the Landsort deep in the Baltic proper (starting at $58^{\circ} 49.8^{\prime} \mathrm{N}$, $19^{\circ} 04.7^{\prime} \mathrm{E}$ and ending at $58^{\circ} 35.3^{\prime} \mathrm{N}, 18^{\circ} 40.5^{\prime} \mathrm{E}$. Water was collected with a 30 l PVC Niskin-bottle at around $0800 \mathrm{~h}$ local time. Nutrients (ammonium, nitrate, urea, and phosphate) were analysed on board by the method of Grasshoff (1976). All filtration and separation into particulate and dissolved fractions was made through Whatman $\mathrm{GF} / \mathrm{F}$ glass fibre filters, precombusted at $450^{\circ} \mathrm{C}$ for $2 \mathrm{~h}$ to remove organic contamination. The filtrate was frozen for later analyses of dissolved organic carbon and nitrogen and the collected particulate material was dried in an evacuated desiccator with silica gel and stored dry until analysis. The analyses of dissolved and particulate matter were performed within 3 mo from sampling.

Analyses of particulate material. Totai amounts of particulate carbon (PC) and nitrogen (PN) were determined with a Carlo Erba Model 1106 Elemental Analyzer. The phosphorus in the particulate matter (PP) was wet-oxidized to orthophosphate by autoclaving at $120^{\circ} \mathrm{C}$ for $60 \mathrm{~min}$, using persulfate as oxidant. This is essentially the method described by Valderrama (1981) for determinations of total phosphorus. ATP was extracted from the particulate material using boiling Tris-EDTA according to Lundin \& Thore (1975) and analysed by the bioluminescence method, using Sigma FLE-50 enzyme extract and a Packard Picolite Model 6100 ATPanalyzer.

Analyses of dissolved organic matter. Total dissolved nitrogen was analysed as nitrate after wet oxidation in UV-radiation, using the method described by Enoksson \& Samuelsson (1987). To obtain the concentration of dissolved organic nitrogen (DON), the amount of inorganic nitrogen was subtracted. Dissolved organic carbon (DOC) was analysed with an infrared carbon analyser (Beckman Total Organic Carbon Analyzer 915 B) by the Askö Laboratory, University of Stockholm.

Uptake rates of ammonium, nitrate and urea. These experiments started on July 27 . Water samples from 0 , 5,10 , and $15 \mathrm{~m}$ depth were enriched with 0.1 or $0.2 \mu \mathrm{mol} \mathrm{N}^{-1}\left(95\right.$ atom $\left.\%{ }^{15} \mathrm{~N}\right)$ of the ${ }^{15} \mathrm{~N}$ labelled nitrogen compound of interest and incubated in 2.61 polycarbonate bottles on deck. The samples were cooled with flowing surface water and the light conditions corresponding to the sampling depths were obtained with neutral density screens. Incubations were carried out around noon and lasted for 4 to $6 \mathrm{~h}$. The particulate material was collected and converted to $\mathrm{N}_{2}$ gas by Dumas oxidation in discharge tubes, according to Kristiansen \& Paasche (1982). The ${ }^{14} \mathrm{~N} /{ }^{15} \mathrm{~N}$ isotope ratio in the $\mathrm{N}_{2}$ was analysed by emission spectrometry (Statron NOI-5 ${ }^{15} \mathrm{~N}$ Analyzer).
When in situ nutrient concentrations are low, the addition of a labelled nutrient might induce an increased uptake rate. The measured uptake values were corrected for this by using Monod kinetics. The $\mathrm{K}_{\mathrm{s}}$-values used, 0.22 and $0.02 \mu \mathrm{mol} \mathrm{N} \mathrm{^{-1 }}$ respectively for ammonium and nitrate, were calculated from incubation series with different nutrient additions made during a later part of the cruise. For corrections of the urea uptake values a $K_{\mathrm{s}}$-value of $0.27 \mu \mathrm{mol} \mathrm{N} \mathrm{l}^{-1}$ was used. This figure is an average derived from summer studies in the North Sea (Kristiansen 1983). Daily nitrogen uptake was calculated by assuming a light dependency for the light period uptake (16 h), which means that the nitrogen uptake per unit of irradiance (Kipp \& Zonen pyranometer) was constant over the day. To this was added a dark uptake estimated to $20 \%$ of the average light period uptake. We consider the estimate of $20 \%$ uptake in the dark to be a conservative estimate when comparing with other studies, e.g. during a similar cyanobacteria bloom in the nearby Askö area in 1984, the nitrogen uptake rate at midnight was $30 \%$ of that at midday (K. Pettersson \& F. Sörensson unpubl.).

\section{RESULTS}

\section{Hydrography}

The nutrient-depleted upper water mass had a temperature of 17 to $18^{\circ} \mathrm{C}$ and was well separated from the deeper water by a sharp thermocline with a gradient of about $1 \mathrm{C}^{\circ} \mathrm{m}^{-1}$, located at 14 to $18 \mathrm{~m}$. Salinity was around $7 \%$ down to the halocline at $70 \mathrm{~m}$.

\section{Nutrients}

All nutrient concentrations above the thermocline were very low: 0.03 to $0.05 \mu \mathrm{mol} \mathrm{l}^{-1}$ of phosphate, 0.11 to $0.21 \mu \mathrm{mol} \mathrm{l}^{-1}$ of ammonium, and 0.17 to $0.30 \mu \mathrm{mol}$ $1^{-1}$ of urea- $\mathrm{N}$. The nitrate concentration was always at or below the detection limit $\left(0.10 \mu \mathrm{mol} \mathrm{l}^{-1}\right.$; Thorstensson 1987).

\section{Particulate material}

The average amounts of particulate carbon and nitrogen above the thermocline were respectively $22.6 \mu \mathrm{mol} \mathrm{Cl^{-1 }}$ (SD 1.2, $\mathrm{n}=71$ ) and $2.66 \mu \mathrm{mol} \mathrm{N} \mathrm{l^{-1 }}$ (SD 0.14, $\mathrm{n}=71$ ), with a PC/PN ratio of 8.5 (Table 1 ). Below the thermocline, the concentrations dropped to about one-fourth of the surface values. There was a slightly increased PC/PN ratio below $25 \mathrm{~m}$, the average ratio being 9.9 . This could be due to a faster mineralization of nitrogen than of carbon in sediment- 
Table 1. Mean values of particulate $\mathrm{C}, \mathrm{N}$, and $\mathrm{P}$, and dissolved organic $\mathrm{C}$ and $\mathrm{N}$ for depth interval 0 to $15 \mathrm{~m}$ or individual depths. All concentrations in $\mu \mathrm{mol} 1^{-1}$

\begin{tabular}{|c|c|c|c|c|c|c|c|c|}
\hline \multirow{2}{*}{$\begin{array}{l}\text { Date (1982) } \\
\text { and depth }\end{array}$} & \multicolumn{5}{|c|}{ Particulate material } & \multicolumn{3}{|c|}{ Dissolved organics } \\
\hline & C & $\mathrm{N}$ & $\mathrm{P}$ & $\mathrm{C} / \mathrm{N}$ & $\mathrm{N} / \mathrm{P}$ & $\mathrm{C}$ & $\mathrm{N}$ & $\mathrm{C} / \mathrm{N}$ \\
\hline \multicolumn{9}{|l|}{$26 \mathrm{Jul}$} \\
\hline $0-15 \mathrm{~m}$ & 26.0 & 2.94 & 0.17 & 8.8 & 18 & 424 & 14.6 & 29 \\
\hline $20 \mathrm{~m}$ & 20.5 & 2.20 & 0.11 & 9.3 & 20 & 706 & 14.4 & 49 \\
\hline $30 \mathrm{~m}$ & 7.9 & 0.72 & 0.03 & 11.0 & 28 & 350 & 13.9 & 25 \\
\hline $40 \mathrm{~m}$ & 5.0 & 0.42 & 0.02 & 11.9 & 21 & 398 & 13.9 & 29 \\
\hline $50 \mathrm{~m}$ & 8.6 & 0.73 & 0.03 & 11.8 & 25 & 383 & 17.0 & 23 \\
\hline $60 \mathrm{~m}$ & 6.2 & 0.70 & 0.05 & 8.9 & 14 & 370 & 13.6 & 27 \\
\hline $70 \mathrm{~m}$ & 8.4 & 0.74 & 0.09 & 11.4 & 9 & 414 & 17.5 & 24 \\
\hline \multicolumn{9}{|l|}{$27 \mathrm{Jul}$} \\
\hline $0-15 \mathrm{~m}$ & 20.8 & 2.48 & 0.16 & 8.4 & 15 & 452 & 15.9 & 28 \\
\hline $20 \mathrm{~m}$ & 17.1 & 1.77 & 0.12 & 9.7 & 14 & 447 & 15.7 & 28 \\
\hline $30 \mathrm{~m}$ & 6.2 & 0.69 & 0.04 & 9.0 & 20 & 342 & 20.4 & 17 \\
\hline $40 \mathrm{~m}$ & 6.6 & 0.54 & 0.01 & 12.2 & 49 & 304 & 16.5 & 18 \\
\hline $50 \mathrm{~m}$ & 4.5 & 0.49 & 0.04 & 9.1 & 14 & 290 & 15.9 & 18 \\
\hline $60 \mathrm{~m}$ & 4.4 & 0.49 & 0.02 & 9.0 & 31 & 343 & 15.0 & 23 \\
\hline $70 \mathrm{~m}$ & 5.7 & 0.55 & 0.02 & 10.4 & 26 & 462 & - & \\
\hline $80 \mathrm{~m}$ & 6.8 & 0.68 & 0.03 & 10.0 & 23 & 364 & 15.1 & 24 \\
\hline $90 \mathrm{~m}$ & 5.9 & 0.73 & 0.08 & 8.1 & 10 & 301 & 12.9 & 23 \\
\hline \multicolumn{9}{|l|}{$28 \mathrm{Jul}$} \\
\hline $0-15 \mathrm{~m}$ & 24.3 & 2.88 & 0.13 & 8.4 & 22 & 410 & 15.7 & 26 \\
\hline $20 \mathrm{~m}$ & 23.6 & 2.78 & 0.18 & 8.5 & 16 & 355 & 13.6 & 26 \\
\hline \multicolumn{9}{|l|}{$29 \mathrm{Jul}$} \\
\hline $0-15 \mathrm{~m}$ & 21.0 & 2.42 & 0.15 & 8.7 & 16 & 344 & 14.8 & 23 \\
\hline $20 \mathrm{~m}$ & 19.2 & 2.32 & 0.14 & 8.3 & 16 & 272 & 14.7 & 19 \\
\hline $30 \mathrm{~m}$ & 6.4 & 0.67 & 0.04 & 9.6 & 17 & 474 & 13.9 & 34 \\
\hline $40 \mathrm{~m}$ & 6.3 & 0.65 & 0.04 & 9.7 & 15 & 246 & 16.8 & 15 \\
\hline $50 \mathrm{~m}$ & 4.7 & 0.48 & 0.04 & 9.8 & 12 & 366 & 16.7 & 22 \\
\hline $60 \mathrm{~m}$ & 4.7 & 0.51 & 0.04 & 9.2 & 12 & 506 & 15.7 & 32 \\
\hline $70 \mathrm{~m}$ & 7.3 & 079 & 0.05 & 9.2 & 17 & - & 14.7 & \\
\hline $80 \mathrm{~m}$ & 6.7 & 0.66 & 0.04 & 10.2 & 17 & - & 14.0 & \\
\hline $90 \mathrm{~m}$ & 9.2 & 1.02 & 0.06 & 9.0 & 16 & - & 14.5 & \\
\hline \multicolumn{9}{|l|}{$30 \mathrm{Jul}$} \\
\hline $0-15 \mathrm{~m}$ & 21.7 & 2.59 & 0.13 & 8.4 & 21 & 339 & 13.9 & 24 \\
\hline $20 \mathrm{~m}$ & 19.5 & 2.34 & 0.15 & 8.3 & 15 & 282 & 13.8 & 20 \\
\hline \multicolumn{9}{|l|}{$31 \mathrm{Jul}$} \\
\hline $0-15 \mathrm{~m}$ & 21.8 & 2.65 & 0.12 & 8.2 & 23 & 369 & 13.4 & 28 \\
\hline $20 \mathrm{~m}$ & 12.7 & 1.35 & 0.11 & 9.4 & 12 & 324 & 13.3 & 24 \\
\hline $25 \mathrm{~m}$ & 9.7 & 1.11 & 0.06 & 8.7 & 20 & 359 & 14.5 & 25 \\
\hline \multicolumn{9}{|l|}{1 Aug } \\
\hline $0-15 \mathrm{~m}$ & - & - & 0.15 & & & 315 & 14.2 & 22 \\
\hline $20 \mathrm{~m}$ & - & - & 0.18 & & & 345 & 15.9 & 22 \\
\hline $25 \mathrm{~m}$ & - & - & 0.17 & & & 452 & 15.1 & 30 \\
\hline
\end{tabular}

ing material. The average concentration of particulate phosphorus was $0.142 \mu \mathrm{mol} \mathrm{l}^{-1}$ (SD 0.011, $\mathrm{n}=83$ ) in the upper water mass, also showing a marked decrease below the thermocline. The $\mathrm{PN} / \mathrm{PP}$ ratio was more variable than the $\mathrm{PC} / \mathrm{PN}$ ratio and did not differ significantly above and below the thermocline. The PN:PP ratio was 19: 1 in the upper water mass. The average ATP value above the thermocline was $190 \mathrm{ng} \mathrm{l}^{-1}$. There was usually a small peak in concentration around the thermocline, at 15 and $20 \mathrm{~m}$ depth. Below
$25 \mathrm{~m}$ the average ATP content was approximately half of the surface value.

\section{Dissolved organic material (DOM)}

Neither the dissolved organic carbon (DOC) nor nitrogen (DON) showed any significant concentration differences that could be correlated with density stratification. The concentrations of DOC were usually 
between 300 and $500 \mu \mathrm{mol} \mathrm{l}^{-1}$, with a slight decrease in the surface values with time (Table 1). Concentrations of DON were generally in the range of 13 to 18 umol $\mathrm{l}^{-1}$ throughout the water column, showing a slight decrease with time. The $\mathrm{C} / \mathrm{N}$ ratio of DOM was generally above 20 .

\section{Uptake of nutrients}

The results indicated a 'steady state' situation for the uptake of nitrogenous nutrients throughout much of the $6 \mathrm{~d}$ drift study. The uncorrected results are shown in Table 2, and those corrected with Monod kinetics in Table 3. In the following text only the corrected rates will be used. Mean values ( 0 to $15 \mathrm{~m}$ depth) for the total uptake of combined nitrogen were 387 to $523 \mathrm{nmol} \mathrm{l}^{-1} \mathrm{~d}^{-1}$, and showed no clear trends with time. Ammonium was the dominant nitrogen source, accounting for 37 to $67 \%$ of the uptake of combined nitrogen, followed by urea-N, 24 to $44 \%$, and nitrate, 9 to $19 \%$.

Table 2. Drift study stations. Sum of uptake and percentages of the individual nitrogen sources of the sum. Means for depth interval 0 to $15 \mathrm{~m}$

\begin{tabular}{|c|c|c|c|c|c|}
\hline \multirow{2}{*}{$\begin{array}{c}\text { Date } \\
(1982)\end{array}$} & \multicolumn{2}{|c|}{ Sum of uptake } & \multicolumn{3}{|c|}{ Percentage of uptake } \\
\hline & $\left(\mathrm{nM} \mathrm{h}^{-1}\right)$ & $\left(\mathrm{nM} \mathrm{d}^{-1}\right)$ & $\begin{array}{l}\text { Ammo- } \\
\text { nium }\end{array}$ & Nitrate & $\begin{array}{l}\text { Urea- } \\
\text { N }\end{array}$ \\
\hline Jul 27 & 40 & 511 & 42 & 16 & 42 \\
\hline 28 & 57 & 570 & 65 & 8 & 28 \\
\hline 29 & 48 & 601 & 57 & 12 & 31 \\
\hline 30 & 51 & 619 & 59 & 9 & 32 \\
\hline 31 & 8 & 645 & 57 & 10 & 33 \\
\hline Aug 1 & 53 & 486 & 56 & 11 & 33 \\
\hline Mean & 51 & 572 & 56 & 11 & 33 \\
\hline $\mathrm{SD}$ & 6.6 & 62.5 & 8 & 3 & 5 \\
\hline
\end{tabular}

\section{DISCUSSION}

The pronounced differences in amount of particulate matter showed that the water mass above the thermocline was very effectively isolated from the water below. Transport of nutrients into the upper water must therefore have been very small. This was also shown by Wilmot (1987) who, based on nutrient data and current measurements from the cruise, calculated that vertical transport was so slow that a period of $90 \mathrm{~d}$ was needed to double inorganic nutrients above the thermocline through entrainment. Production in the upper water mass had, except for input of $\mathrm{N}_{2}$ to nitrogen-fixing organisms, to rely on regenerating processes.

Besides inorganic nutrients, another source for phytoplankton growth is dissolved organic matter, which dominated the organic nitrogen in the upper water mass to more than $80 \%$. At present, we lack appropriate methods for determining the amount of dissolved organic matter which is easily utilized by microorganisms, although the homogenous distribution of dissolved organic nitrogen and carbon throughout the water column indicates that the major part is degraded slowly and is not closely coupled to the biological processes in the photic zone. Ogura (1975) estimated the more stable, refractive part of the dissolved organic carbon to be 80 to $90 \%$ in open sea water. It is probable that this part is even larger in the Baltic due to a discharge of refractive organic substances of terrestrial origin (Fonselius 1972). This is reflected in the high C/ $\mathrm{N}$ ratio, generally above 20 , of the dissolved organic matter (Table 1) which can be compared to for example the value of 8 given as a coastal average by Sharp et al. (1982). Gabrielson \& Hamel (1985) showed that Nodularia spumigena cells, when decomposing, rapidly released both dissolved organic and inorganic nitrogen and phosphorus in forms available to other algae; thus decaying cells could constitute an important source for regeneration of nutrients. Some of the

Table 3. Same as Table 2, but corrected for enrichment effects. Calculated maximal uptake rate values $\left(V_{\max }\right)$ expressed as nmol $\mathrm{l}^{-1} \mathrm{~h}^{-1}$, and individual nitrogen sources as percent of corrected total nitrogen uptake

\begin{tabular}{|c|c|c|c|c|c|c|c|c|}
\hline \multirow[t]{2}{*}{ Date } & \multicolumn{2}{|c|}{ Sum of uptake } & \multicolumn{2}{|c|}{ Ammonium } & \multicolumn{2}{|c|}{ Nitrate } & \multicolumn{2}{|c|}{ Urea } \\
\hline & $\left(\mathrm{nM} \mathrm{h}^{-1}\right)$ & $\left(n \mathrm{M} \mathrm{d}^{-1}\right)$ & $\mathrm{V}_{\max }$ & $\%$ & $V_{\max }$ & $\%$ & $\mathrm{~V}_{\operatorname{rax}}$ & $\%$ \\
\hline Jul 27 & 31 & 450 & 34 & 37 & 7 & 19 & 26 & 44 \\
\hline 28 & 45 & 448 & 65 & 67 & 5 & 9 & 27 & 24 \\
\hline 29 & 36 & 457 & 50 & 58 & 6 & 14 & 26 & 28 \\
\hline 30 & 40 & 490 & 54 & 60 & 5 & 109 & 27 & 30 \\
\hline 31 & 47 & 523 & 56 & 59 & 6 & 11 & 31 & 30 \\
\hline Aug 1 & 42 & 387 & 51 & 58 & 6 & 13 & 29 & 29 \\
\hline Mean & 40 & 395 & 52 & 56 & 6 & 13 & 28 & 31 \\
\hline $\mathrm{SD}$ & 5.9 & 52.7 & 10.1 & 10 & 0.9 & 4 & 2.2 & 7 \\
\hline
\end{tabular}


regenerated nutrients might have been a suitable source for heterotrophic bacteria. Wheeler \& Kirchman (1986) showed from ${ }^{15} \mathrm{~N}$ uptake experiments off the coast of Georgia that about $80 \%$ of the measured ammonium uptake could be due to bacterial assimilation. However, results from the present cruise (Hagström 1987) indicate that the bacteria played a minor role, having a low growth rate and a very low biomass.

The higher concentration of particulate matter above the thermocline indicated that the major part originated from biological activity in the photic zone. Although the total particulate carbon analysed comprised both living and dead fractions, ATP is only associated with the living, and may be used with some caution to partition between the 2 fractions. Applying the factor 250 for converting the ATP content to 'living carbon' (Holm-Hansen 1970) would give, as an aver-

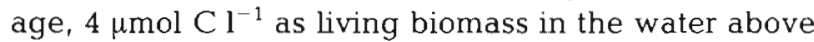
the thermocline. This would constitute about $20 \%$ of the total particulate carbon, which seems low when comparing with e.g. Gordon et al. (1979) who found 26 to $45 \%$ when using the same conversion factor. Gabrielson \& Hamel (1985) estimated the refractory part of Nodularia spumigena to be $34 \%$ of the dry weight, and one source of the large proportion of dead particulate matter could be partly degraded cyanobacteria. The $\mathrm{C} / \mathrm{N}$ ratio of 8.5 therefore seemed to largely reflect partly decomposed dead matter, and this ratio in the living organisms could well be lower. The PN : PP ratio of $19: 1$ indicated no pronounced imbalance of nitrogen to phosphorus, when compared to the ratio of $16: 1$ for phytoplankton composition (Redfield et al. 1963).

The average molar relation between measured uptake rates of carbon, measured by the ${ }^{14} \mathrm{C}$-technique (Lindahl 1987), and nitrogen was 4.4 for combined nitrogen and 3.7 if the dinitrogen fixation (Lindahl 1987) was included. This is low when compared to the classical value of 6.6 for phytoplankton composition (Redfield et al. 1963), or to the mean $\mathrm{C} / \mathrm{N}$ ratio of 8.5 in the particulate material. Lower uptake ratios than 6.6 were also observed by e.g. Eppley et al. (1973) in the Central Gyre of the North Pacific (3.0 to 7.7, integrated over the $150 \mathrm{~m}$ euphotic zone). The low assimilation ratio could indicate that the phytoplankton did not experience nitrogen limitation. It could, however, also indicate overestimation of the nitrogen uptake and/or underestimation of the carbon uptake.

One possible source of error for nitrogen uptake rate calculations found by e.g. Murphy (1980) could be that the biologically available in situ nutrient concentration was overestimated by the chemical analysis. This would lead to an overestimation of nitrogen uptake, especially at low additions of labelled substrate. This is probably the case for the nitrate uptake, where we used the detection limit $\left(0.1 \mu \mathrm{mol}{ }^{-1}\right)$ as the in situ ambient concentration, even if the concentration probably was lower. According to our kinetic studies during a later part of the cruise, the phytoplankton apparently had a low $\mathrm{V}_{\text {max }}$ for nitrate uptake, which indicated an adaptation to low concentrations. The addition $\left(0.1 \mathrm{mmol} \mathrm{l}^{-1}\right)$ of nitrate to the water sample therefore only resulted in a small increase in uptake. The average nitrate uptake rate during our study was $59 \mathrm{nmol} \mathrm{N}^{-1} \mathrm{~d}^{-1}$. If the supply of nitrate through entrainment is negligible, the only other source available is nitrification. The highest nitrification rate obtained by Enoksson (1986) above $50 \mathrm{~m}$ was

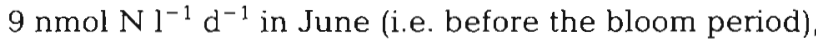
in the same year and the same area as this study. Possible explanations for this apparent discrepancy between uptake and supply of nitrate could have been higher nitrification rates during our study period, or overestimate of the nitrate uptake rate.

Another feature that might be explained by overestimation of the biologically available in situ concentration was the results from the kinetic experiments on urea uptake performed during a later part of the cruise. The calculated rates decreased with increasing concentration, and no $\mathrm{K}_{\mathrm{s}}$ or $\mathrm{V}_{\max }$ could be determined. For this reason we used a $K_{\mathrm{s}}$ value from the literature. One approach, used by e.g. Murphy (1980), is to lower the value for in situ nutrient concentration used in the calculations of uptake until Monod kinetics is achieved. When lowering the value for ambient urea concentrations to $0.05 \mu \mathrm{mol} \mathrm{N} \mathrm{^{-1 }}$ instead of the measured value of about $0.20 \mu \mathrm{mol} \mathrm{N} \mathrm{l}^{-1}$; the resulting kinetic constants gave an uptake of $30 \%$ of the measured urea uptake rate. Applying this to the present data would give a corrected uptake rate of $57 \mathrm{nmol}$ urea- $\mathrm{N}^{-1} \mathrm{~d}^{-1}$. Only $13 \%$ of the total nitrogen taken up would then be urea, while nitrogen fixation would constitute $19 \%$ of the total. Since an overestimation of the concentrations cannot be proven, we have used the uptake calculated from the measured urea concentrations throughout this paper.

On the other hand, the isotope dilution effect caused by regeneration of unlabelled nutrients during the incubation, probably most important for ammonium (Glibert et al. 1982, Harrison \& Harris 1986), would lead to underestimation of the uptake rate. This error would, however, be expected to be more pronounced for long incubations (i.e. $24 \mathrm{~h}$ ), while ours lasted 4 to $6 \mathrm{~h}$. The effect of diluting the ${ }^{15} \mathrm{~N}$-labelled ammonium through regeneration would, if the regeneration rate equalled the uptake, underestimate our ammonium uptake values by at most $10 \%$ under the prevailing conditions. We have not corrected our uptake data for this effect, but it would not have influenced the general conclusions. Nutrient concentrations and uptake rates showed little change over the $6 \mathrm{~d}$ drift study, and 
therefore to maintain a steady state, regeneration would have had to be of the same size as uptake.

To use the concept of 'new' versus 'regenerated' production introduced by Dugdale \& Goering (1967), one must be able to distinguish between the supply of the 2 classes of nitrogen nutrients. In waters where significant external sources of regenerated nutrients exist, the concept may be of no practical use. In the present case, all sampling was carried out far from the coast, and in stratified water masses with depths always exceeding $80 \mathrm{~m}$. Any influence of ammonium or urea from land or sediments could have been of no practical consequence, and the use of uptake of these nutrients for estimating regenerated production is justified. The 'new' production, based on uptake of nitrate and $\mathrm{N}_{2}$, constituted $27 \%$ of the overall nitrogen uptake. The measured sedimentation rate, $85.7 \mathrm{nmol} \mathrm{N}$ $1^{-1} \mathrm{~d}^{-1}$, during the same study (Cederwall 1987) corresponded to $59 \%$ of the new production. The difference could be due to degradation of organic material inside the sediment traps, to incomplete capture of sedimenting matter, to overestimation of nitrate uptake (see above), or to a temporary accumulation of nitrogen into different fractions in the upper water mass (e.g. floating patches of decaying cyanobacteria which were seen on the sea surface). The accumulation in the upper water mass would be equivalent to $0.3 \mu \mathrm{mol} \mathrm{N}^{-1}$ during the investigated period, which is within analytical errors when analysing all nitrogen fractions.

The finding that ammonium was the preferred nutrient source, followed by urea, is in agreement with other studies from different parts of the world (e.g. McCarthy \& Eppley 1972, Harvey \& Caperon 1976). Even during this study, when there was a bloom of cyanobacteria, the nitrogen fixation rate, $86 \mathrm{nmol} \mathrm{N}{ }^{-1}$ $\mathrm{d}^{-1}$, measured on parallel samples (Lindahl 1987), only reached $16 \%$ of the total nitrogen $\left(\mathrm{NH}_{4}^{+}+\mathrm{NO}_{3}^{-}+\right.$ urea- $\mathrm{N}+\mathrm{N}_{2}$ ) utilization, while the ammonium uptake constituted $47 \%$. The low contribution of nitrogen fixation to total nitrogen uptake might be explained by a rapid regeneration of reduced nitrogen, mainly utilized by the large number of small (less than $10 \mu \mathrm{m}$ ) phytoplankton (Wallström 1987). These were responsible for $80 \%$ of the primary production, but no significant nitrogen fixation was shown in this fraction (Lindahl 1987).

The turnover time of particulate organic nitrogen was $3.8 \mathrm{~d}$ if nitrogen fixation is included. The living organisms were estimated to constitute $23 \%$ of the total particulate organic nitrogen or $0.6 \mu \mathrm{mol} \mathrm{l}^{-1}$, based on ATP measurements and assuming a ratio between $\mathrm{C}$ and $\mathrm{N}$ in phytoplankton of 6.6:1 (Redfield et al. 1963). The amount of nitrogen in the living phytoplankton has been calculated from microscopic wet weight estimates (Wallström 1987) assuming carbon content to be $11 \%$ of wet weight (Edler 1979) and a Redfield $\mathrm{C}: \mathrm{N}$ ratio. The phytoplankton biomass would then constitute on average $0.56 \mu \mathrm{mol} \mathrm{N}^{-1}$, i.e. $21 \%$ of the total PN, giving a growth rate for the phytoplankton population of one doubling per day.

If we assume: (1) that total nitrogen uptake in the size fractions larger and smaller than $10 \mu \mathrm{m}$ is proportional to primary production in these fractions, (2)

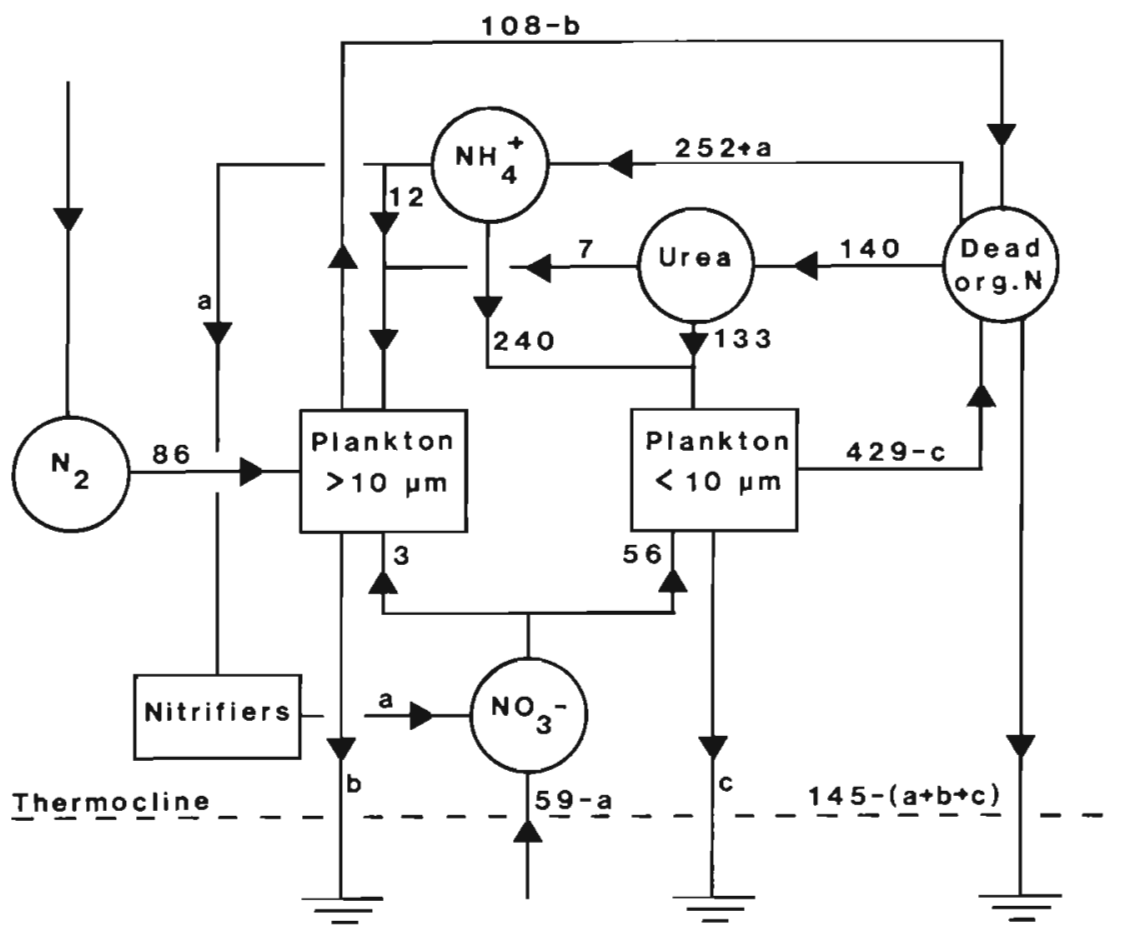

Fig. 1. Model of nitrogen transformations above the thermocline, assuming steadystate conditions and $\mathrm{N}$-uptake in the 2 size fractions in the same proportions as C-uptake (Lindahl 1987). Only the fraction larger than $10 \mu \mathrm{m}$ is assumed to fix $\mathrm{N}_{2}$. Rates are given in nmol $\mathrm{N} \mathrm{l}^{-1} \mathrm{~d}^{-1}$. Rates a (nitrification), $\mathrm{b}$ and $\mathrm{c}$ (sedimentation of the 2 plankton compartments) are unknown 
that the size fraction smaller than $10 \mu \mathrm{m}$ does not fix $\mathrm{N}_{2}$, and (3) that we have steady-state conditions, then a model of the nitrogen transformations above the thermocline can be constructed. This is shown in Fig. 1. According to this, small algal cells account for an $\mathrm{N}$ uptake of $429 \mathrm{nmol} \mathrm{N} \mathrm{l}^{-1} \mathrm{~d}^{-1}$, which means that they are responsible for $95 \%$ of the total uptake of combined nitrogen. This is in good agreement with our measurements in the Asko area in the same season in 1984 and 1985, when more than $80 \%$ of the uptake of combined nitrogen was associated with the fraction smaller than $10 \mu \mathrm{m}$ (K. Pettersson, E. Sahlsten and F. Sörensson, unpubl.). For the fraction larger than $10 \mu \mathrm{m}$, nitrogen fixation would then account for $80 \%$ of the nitrogen taken up. This could well be the case, since this fraction was dominated by filamentous cyanobacteria, capable of nitrogen fixation (Wallström 1987).

Acknowledgements. We thank the scientists and crew of $\mathrm{R} / \mathrm{V}$ Georgii Ushakov for all help during the cruise, Anna-Kerstin Thell and Christina Westberg for skilful technical assistance, and Bodil Thorstensson (SMHI Oceanographical Dept.) for the use of her nutrient data. We also appreciate the access to data 'in press' by Hans Cederwall, Viveka Enoksson, Ảke Hagström, Gunvor Lindahl, Matts-Ola Samuelsson, Kerstin Wallstrom, and Wayne Wilmot. Drs. Ulf Rönner, Peter J. leB. Williams, and Fredrik Wulff gave helpful comments on the manuscript. Financial support from the Swedish Environment Protection Board (grant No. 5312072-1) is gratefully acknowledged.

\section{LITERATURE CITED}

Brattberg, G. (1980). Kvävefixering i marin miljö - Ostersjön. Swedish Environmental Protection Board, Report P.M. 1213: $95-103$

Cederwall, H. (1987). Sedimentation during a Nodularia bloom. In: Cederwall, H. (ed.) Dynamics of a Nodularia bloom. Swedish Environmental Protection Board, Report P.M. (in press)

Dugdale, R. C., Goering, J. J. (1967). Uptake of new and regenerated forms of nitrogen in primary productivity. Limnol. Oceanogr. 12: 196-206

Edler, L. (1979). Recommendations on methods for marine biological studies in the Baltic Sea. Phytoplankton and chlorophyll. The Baltic Marine Biologists, Lund, Publ. 5: p. $1-36$

Enoksson, V. (1986). Nitrification rates in the Baltic Sea: comparison of three isotope techniques. Appl. environ. Microbiol. 51: 244-250

Enoksson, V., Samuelsson, M.-O. (1987). Nitrification and dissimilatory ammonium production and their effects on nitrogen flux over the sediment-water interface in bioturbated coastal sediments. Mar. Ecol. Prog. Ser. 36: 181-189

Eppley, R. W., Peterson, B. J. (1979). Particulate organic matter flux and planktonic new production in the deep ocean. Nature, Lond. 282: 677-680

Eppley, R. W., Renger, E. H., Venrick, E. L., Mullin, M. M. (1973). A study of plankton dynamics and nutrient cycling in the Central Gyre of the North Pacific Ocean. Limnol. Oceanogr. 18: 534-551
Fonselius, S. H. (1972). On biogenic elements and organic matter in the Baltic. Ambio Spec. Rep. 1: 29-36

Fonselius, S. H. (1978). On nutrients and their role as production limiting factors in the Baltic. Acta hydrochim. hydrobiol. 6: 329-339

Gabrielson, J. O., Hamel, K. S. (1985). Decomposition of the cyanobacterium Nodularia spumigena. Botanica mar. 28: 23-27

Glibert, P. M., Lipschultz, F., McCarthy, J. J., Altabet, M. A (1982). Isotope dilution models of uptake and remineralization of ammonium by plankton. Limnol. Oceanogr. 27 : $639-650$

Gordon, D. C., Jr., Wangersky, P. J., Sheldon, R. W. (1979). Detailed observations on the distribution and composition of particulate organic material at two stations in the Sargasso Sea. Deep Sea Res. 26: 1083-1092

Granéli, E., Granéli, W. (1987). Eutrophication and dinoflagellate blooms in Swedish coastal waters - possible causes and countermeasures. In: Chao, N. L., Kirby-Smith, W. (ed.) International Symposium on Utilization of Coastal Ecosystems: planning, pollution and productivity (1982: Rio Grande, RS, Brazil), Vol. II. Duke Univ. Marine Laboratory, Beaufort, USA (in press)

Grasshoff, K. (1976). Methods of seawater analysis. Verlag Chemie, Weinheim

Hagström, $\hat{\AA}$. (1987). Distribution of bacteria during a Nodularia bloom. In: Cederwall, H. (ed.) Dynamics of a Nodularia bloom. Swedish Environmental Protection Board, Report P.M. (in press)

Harrison, W. G., Harris, L. R. (1986). Isotope-dilution and its effects on measurements of nitrogen and phosphorus uptake by oceanic microplankton. Mar. Ecol. Prog. Ser. 27 : 253-261

Harvey, W. A., Caperon, J. (1976). The rate of utilization of urea, ammonium, and nitrate by natural populations of marine phytoplankton in a eutrophic environment. Pacif. Sci. 30: 329-340

Holm-Hansen, O. (1970). A.TP levels in algal cells as influenced by environmental conditions. Pl. Cell Physiol., Tokyo 11: 689-700

Kristiansen, S. (1983). Urea as a nitrogen source for the phytoplankton in the Oslofjord. Mar. Biol. 74: 17-24

Kristiansen, S., Paasche, E. (1982). Preparation of N-15 labelled phytoplankton samples for optical emission spectrometry. Limnol. Oceanogr. 27: 373-375

Larsson, U. (1984). Produktionsbegränsande ämnen, In: Rosenberg, R. (ed.) Gödning av havsomrâden kring Sverige. Swedish Environment Protection Board, Report P.M. 1808: $17-73$

Larsson, U., Elmgren, R., Wulff, F. (1985). Eutrophication and the Baltic Sea: causes and consequences. Ambio 14: 10-14

Larsson, U., Hagström, А. (1982). Fractionated phytoplankton primary production, exudate release and bacterial production in a Baltic eutrophication gradient. Mar. Biol. 67 : $57-70$

Lindahl, G. (1987). Nitrogen fixation, primary production and phosphatase activity during a Nodularia bloom. In: Cederwall, H. (ed.) Dynamics of a Nodularia bloom. Swedish Environmental Protection Board, Report P.M. (in press)

Lindahl, G., Wallström, K., Brattberg, G. (1978). On nitrogen fixation in a coastal area of the northern Baitic. Kieler Meeresforsch. (Sonderh.) 4: 171-177

Lundin, A., Thore, A. (1975). Comparison of methods for extraction of bacterial adenine nucleotides determined by firefly assay. Appl. Microbiol. 30: 713-721

McCarthy, J. J., Eppley, R. W. (1972). A comparison of chemical, isotopic and enzymatic methods for measuring nitro- 
gen assimilation of marine phytoplankton. Limnol. Oceanogr. 17: 371-383

Murphy, T. P. (1980). Ammonia and nitrate uptake in the lower Great Lakes. Can. J. Fish. Aquat. Sci. 37: 1365-1372

Niemi, Å. (1979). Blue-green algal blooms and N:P ratio in the Baltic Sea. Acta bot. fenn. 110: 57-61

Ogura, N. (1975). Further studies on decomposition of dissolved organic matter in coastal seawater. Mar. Biol. 31: 101-111

Redfield, A. C., Ketchum, B. H., Richards, F. A. (1963). The influence of organisms on the composition of sea water. In: Hill, M. N. (ed.) The sea, Vol. 2. Wiley, New York, p. $26-77$

Rinne, I., Melvasalo, T., Niemi, A., Niemistö, L. (1978). Nitrogen fixation by blue-green algae in the Baltic Sea. Kieler Meeresforsch. (Sonderh.) 4: 178-187

Sharp, J. H., Frake, A. C., Hillier, G. B., Underhill, P. A. (1982). Modelling nutrient regeneration in the ocean with an aquarium system. Mar. Ecol. Prog. Ser. 8: 15-23
Thorstensson, B. (1987). Evaluation of results from a survey of nutrients during summer conditions in the Baltic proper. In: Cederwall, H. (ed.) Dynamics of a Nodularia bloom. Swedish Environmental Protection Board, Report P. M. (in press)

Valderrama, J. C. (1981). The simultaneous analysis of total nitrogen and total phosphorus in natural waters. Mar. Chem. 10: 109-122

Wallström, K. (1987). Phytoplankton composition and biomass during a Nodularia bloom in the Baltic 1982. In: Cederwall, H. (ed.) Dynamics of a Nodularia bloom. Swedish Environmental Protection Board, Report P.M. (in press)

Wheeler, P. A., Kirchman, D. L. (1986). Utilization of inorganic and organic nitrogen by bacteria in marine systems. Limnol. Oceanogr. 31: 998-1009

Wilmot, W. (1987). Vertical fluxes during a blue-green algae bloom in the Baltic Sea. In: Cederwall, $H$. (ed.) Dynamics of a Nodularia bloom. Swedish Environmental Protection Board, Report P.M. (in press)

This article was submitted to the editor; it was accepted for printing on March 2, 1987 